\title{
Corporate Governance: A Look through the Auditing Lens with reference to India
}

\author{
Shalini TALWAR ${ }^{\star}$, Chitra PUNDIR ${ }^{\star}$
}

\begin{tabular}{l}
\hline \multicolumn{1}{c}{ A R T I C L E I N F O } \\
\hline Article history: \\
Accepted January 2019 \\
Available online April 2019 \\
\hline JEL Classification \\
G30 \\
Keywords: \\
Auditing, Corporate Governance, \\
Indian Corporate Sector, PNB Scam
\end{tabular}

Indian Corporate Sector, PNB Scam

\begin{abstract}
A B S T R A C T
In today's scenario, corporate governance has become a very important concern in India as many scams have been emerging in the recent past in many companies in public and private sectors in India that have their roots in the governance-related misadventures. The current study is aimed at studying the relationship between auditing and corporate governance. It highlights the role of responsible auditing as a tool for improving the corporate governance practices in Indian companies. Ten leading companies have been selected based on their market capitalization to analyze auditing practices in India. Further, to gain a deeper insight into the anatomy of corporate scams and to understand the causes of governance failures in Indian companies, the recent PNB scam has also been analyzed in detail. The findings of the study are expected to be useful to companies in implementing better governance practices and to regulators in formulating more effective codes and standards for enforcing good governance.
\end{abstract}

(C) 2019 EAI. All rights reserved.

\section{Introduction}

Corporate governance (CG) ensures that companies are run in such a way that the interests of all their stakeholders (internal or external) remain protected. Internal stakeholders include promoters, members, and employees. External stakeholders mainly include customers, lenders, vendors, bankers, community, government, auditors, and regulators.

Corporate governance consists of a set of proper and feasible relationships connecting company management with its shareholders and stakeholders. It also provides a basis for the formulation of company's objectives, laying down the processes for achieving them and monitoring the performance thereafter. It not only lays down the duties of the directors but also the decision making rules for corporates. Governance has assumed significance in the recent times after a series of corporate failings and frauds in India which have caused the investors to lose confidence in the Indian corporate sector.

Maximization of shareholders' wealth, investor protection, and transparency are the main aims of corporate governance and its goal is to achieve the alignment of the interests of different stakeholders. An effective corporate governance system can be expected to provide a mechanism for regulating directors' duties in order to restrain directors/managers from misusing their powers to impair investors' interests. CG encompasses director's responsibilities, disclosures, corporate and financial reporting, remuneration committee, audit committee(AC) and shareholders grievance committee as illustrated in figure 1.

Figure 1: Facets of corporate governance

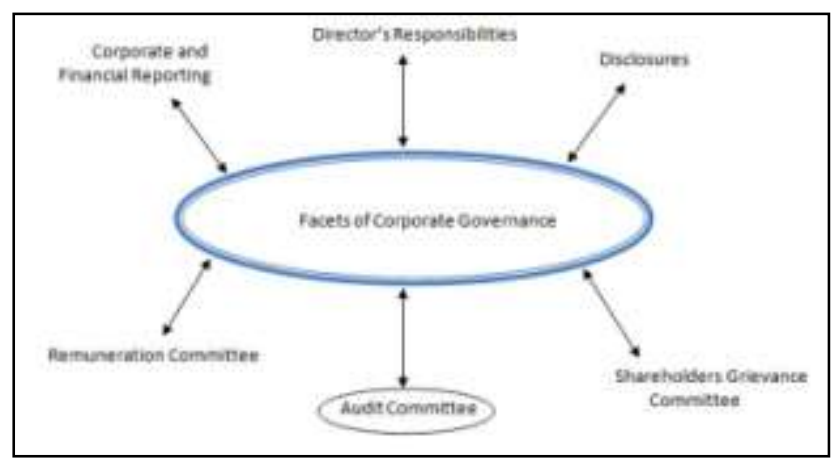

$\stackrel{\star}{\star \star \star}{ }^{\star} \mathrm{K} J$ Somaiya Institute of Management Studies and Research, Mumbai, India. E-mail address: shalini.t@ @omaiya.edu (S. Talwar - Corresponding author), chitra.pundir@somaiya.edu (C. Pundir) 
With focus shifting to CG, one area that has received a lot of attention in India is the role of auditing. This can be seen as the legacy of the Satyam scam of 2008, where auditing failure was identified as a prominent factor in the fraud going undetected for a considerable time. Even before the surfacing of this scam, discussions related to auditing and governance were being held in India. The linkage between auditors and good corporate governance came into focus after the publication of a report submitted by the Kumar Mangalam Birla Committee on corporate governance in 1999 (SEBI circular, 2000), a committee appointed by the Securities and Exchange Board of India (SEBI). The formulation of this committee was motivated mainly by the financial crisis that was rearing its head in the emerging markets like India. In the year 2000, the committee gave various recommendations that paved the way for adoption of Clause 49, which dealt with issues related to corporate governance. The clause stipulated that companies that were listed on any Indian stock exchange were required to include CG report in their annual reports and this report had to mandatorily mention any non-compliance with the prerequisites of Clause 49, giving specific reasons for the noncompliance.

Later there were many other committees appointed by the SEBI in order to improve CG practices in India to bring them at par with the standards evolving worldwide. Two prominent committees formed for this purpose were the Naresh Chandra Committee, 2002 and the Narayana Murthy Committee, 2003.The Naresh Chandra Committee on Corporate Audit and Governance, 2002 was formed by the Ministry of Finance and Company Affairs after the introduction of the Sarbanes-Oxley Act (SOX) in the US. Key recommendations were aimed at audit committee functioning, functioning of other committees, strengthening of audits in the corporate sector and punitive mechanisms for auditors. The Narayana Murthy Committee on CG, 2003 recommended changes in Clause 49 of the Listing Agreement.

Understanding the key role of auditing in ensuring good governance, the current study aims to analyze the role of AC as a tool of CG in the India. To achieve the objective of the study, various aspects of the functioning of $\mathrm{AC}$ in some Indian companies have been analyzed.

\section{Literature review}

Many studies have highlighted the importance of effective corporate governance including a study by Mohamad (2004), Moeller (2015) and Lessambo (2018).

Cadbury Committee defined "Corporate Governance" in its report "Financial Aspects of Corporate Governance, 1992", as "the system by which companies are directed and controlled". It gives recommendations on board's arrangement and accounting systems to lessen failures of corporate governance (United Kingdom Shareholders' Association, 1992).

La Porta et al. (2000) and Shleifer \&Vishny (1997) described CG as "a set of mechanisms through which outside investors protect themselves against expropriation by controlling owners".

According to OECD, "corporate governance provides a set of relationships which company's board, its management, its shareholders and other stakeholders should maintain among themselves and it also provides the rules and regulations through which the objectives of the company are made" (Co-operation and Development, O. for E., 1999).

Hay et al. (2016) discussed the role of auditing and CG in Australia and New Zealand to highlight the importance of CG in these two countries. He analyzed the relationship between auditing and CG in the selected geographies. Beisland et al. (2015) analyzed nearly seventy microfinance institutions in order to examine the relationship between auditing and CG in the sector. Mahdavi \& Daryaei (2016) used social action theory to understand the impact attitude towards marketing activities on auditing and corporate governance. Auci (2006) analyzed the role of internal auditing as a means to reduce transaction costs associated with asymmetric information. Re-emphasizing the importance of internal audit, Elbardan \& Kholeif (2017) underscored the importance of auditing in governance and established the catalyzing role of ERP systems improved in internal audit functions. Christopher (2012) analyzed the impact of changing control paradigms on internal auditing. Mihret \& Grant (2017) and Joksimovic \& Alseddig (2017) also identified internal audit as a key component of corporate governance.

Porte et al. (2018) analyzed Sarbanes-Oxley Act (SOX) in a study which identified different themes in auditing and its association with post-SOX Act era. Taking the discussion beyond internal audit, Kurihama (2007) in an article "A New Perspective between Corporate Governance and Auditing" examined the impact of independent auditing on corporate governance. In their study on independent auditing and corporate governance, Rodgers et al. (2007) argued that independent auditing has the power to influence accountability. Sonu et al. (2017) investigated the relationship between corporate governance and two aspects of external audit, namely, audit fees and audit hours in the post and pre-financial crisis periods. In their study related to fraud, auditing and governance, Pagano \& Immordino (2012) argued how managers tended to misreport information during the liquidation process and emphasized the role of audit quality and managerial compensation in designing corporate governance mechanism. Thus, the existing literature has clearly established the importance of auditing mechanism in ensuring better governance. 


\section{Methods and Data}

This study has examined the importance of AC as a tool of CG in India. Ten listed Indian companies have been identified and analysed from the perspective of auditing practices. In addition, the recent PNB scam (Dsouza, 2018), has also been analysed to underscore the importance of auditing in corporate governance. Companies have been shortlisted based on their market capitalization except PNB, which is analysed in order to highlight the loopholes in different processes. Data for the study has been extracted from secondary sources, namely, CG reports, annual reports and websites. The case survey method is adopted for achieving the objectives of the study. Inferences have been drawn by analyzing the CG philosophy and the AC charters of the selected companies. A brief profile of these companies is given in table 1.

Table 1: Profile of companies

\begin{tabular}{|c|c|c|c|c|}
\hline S. no & Company & $\begin{array}{c}\text { Market Capitalization in INR } 10 \\
\text { Million }\end{array}$ & $\begin{array}{c}\text { Profit in INR } 10 \\
\text { Million }\end{array}$ & Business \\
\hline 1 & TCS & 580890.57 & 26357.00 & IT \\
\hline 2 & Reliance & 577751.85 & 31425.00 & $\begin{array}{l}\text { Conglomerate- energy, } \\
\text { petrochemicals, textiles, natural } \\
\text { resources, retail, and } \\
\text { telecommunications. }\end{array}$ \\
\hline 3 & HDFC Bank & 480675.75 & 40106.06 & Bank \\
\hline 4 & ITC & 316398.74 & 10477.23 & $\begin{array}{l}\text { Conglomerate-(FMCG), Hotels, } \\
\text { Paperboards \& Packaging, Agri } \\
\text { Business \& IT }\end{array}$ \\
\hline 5 & HUL & 281514.77 & 4502.00 & Consumer goods \\
\hline 6 & Maruti Suzuki & 261735.76 & 7511.00 & Automobile manufacturer \\
\hline 7 & SBI & 218520.44 & 3521.06 & PSU Bank \\
\hline 8 & Infosys & 254099.71 & 14353.00 & IT \\
\hline 9 & ONGC & 230549.07 & 21478.35 & Multinational-Oil and gas company \\
\hline 10 & PNB & 23164.36 & 901.13 & PSU Bank \\
\hline
\end{tabular}

Source : Websites of selected companies

\section{Analysis and Interpretation}

The outcome of analysis of the AC charters and the PNB scam are given in this section.

\subsection{Analysis of AC Practices}

The analysis of the AC practices prevalent in the above mentioned companies has been divided under the following headings:

\subsubsection{Compliance of General Provisions of AC}

Considering the compliance of general provisions of the $\mathrm{AC}$ as given in table 2 , it is observed that all 10 companies under the study have an $\mathrm{AC}$ with an independent director as its chairman. All companies have the required number of independent members in the AC except PNB which might to seen as the major reason for the scam remaining undetected 7 long years before being caught. The chairman of the AC is present at Annual General Meetings (AGM) in case of almost every company for any clarification sought by the shareholders. Such a system goes a long way in boosting the morale of the stakeholders of the company. All companies adopted whistleblower policy except PNB in order to raise voice against any devious activity taking place in company.

Table 2: General Provisions of Audit Committee

\begin{tabular}{|c|c|c|c|c|c|}
\hline Company & $\begin{array}{l}\text { Have audit } \\
\text { committee }\end{array}$ & $\begin{array}{c}\text { Required no of } \\
\text { Independent } \\
\text { members in Audit } \\
\text { Committee } \\
\end{array}$ & $\begin{array}{c}\text { Chairman of Audit Committee } \\
\text { Present in AGM }\end{array}$ & $\begin{array}{l}\text { Overall } \\
\text { Review } \\
\text { Process }\end{array}$ & $\begin{array}{c}\text { Committee adopted Whistle } \\
\text { Blower Policy to ensure } \\
\text { Prevention of Fraud and } \\
\text { Unethical Behaviour }\end{array}$ \\
\hline TCS & $\mathrm{Y}$ & $\mathrm{Y}$ & $\mathrm{Y}$ & $\mathrm{Y}$ & $\mathrm{Y}$ \\
\hline Reliance & $\mathrm{Y}$ & $\mathrm{Y}$ & $\mathrm{Y}$ & $\mathrm{Y}$ & $\mathrm{Y}$ \\
\hline HDFC Bank & $\mathrm{Y}$ & $\mathrm{Y}$ & $\mathrm{Y}$ & $\mathrm{Y}$ & $\mathrm{Y}$ \\
\hline ITC & $\mathrm{Y}$ & $\mathrm{Y}$ & Not Mentioned & $\mathrm{Y}$ & $\mathrm{Y}$ \\
\hline HUL & $\mathrm{Y}$ & $\mathrm{Y}$ & $\mathrm{Y}$ & $\mathrm{Y}$ & $\mathrm{Y}$ \\
\hline Maruti Suzuki & $\mathrm{Y}$ & $\mathrm{Y}$ & $\mathrm{Y}$ & $\mathrm{Y}$ & $\mathrm{Y}$ \\
\hline SBI & $\mathrm{Y}$ & $\mathrm{Y}$ & $\mathrm{Y}$ & $\mathrm{Y}$ & $\mathrm{Y}$ \\
\hline Infosys & $\mathrm{Y}$ & $\mathrm{Y}$ & $\mathrm{Y}$ & $\mathrm{Y}$ & $\mathrm{Y}$ \\
\hline ONGC & $\mathrm{Y}$ & $\mathrm{Y}$ & Not Mentioned & $\mathrm{Y}$ & $\mathrm{Y}$ \\
\hline PNB & $Y$ & $\mathbf{N}$ & $\begin{array}{l}\text { Not clear- Chairman of BoD was } \\
\text { present, Audit committee } \\
\text { chairman not clear from } \\
\text { corporate governance report }\end{array}$ & $\mathbf{N}$ & $\mathbf{N}$ \\
\hline
\end{tabular}

Source: Websites of selected companies 


\subsubsection{Auditor's Role with regard to Financial Statements, Audit and Disclosure}

Taking into consideration all the parameters regarding financial statements, audit and disclosures as given in table 3, audit committees of almost all top companies comply fully with various prescribed aspects. Audit committees of almost all companies oversee the financial reporting process except for PNB because scam of such a large magnitude does not happen in a day. It took years i.e. previous financial reporting was not done properly. The presence of financial experts in companies ensures proper review of quarterly as well as yearly financial statements. For catching a scam like PNB, person who is savvy in handling large number of transactions is required. Moreover, audit committees of all the top companies duly provide for probe into financial irregularities, if any. Also there is a specific committee in each company which checks whether the implementation of policies is done properly or not. So, the committee really works as the financial controller of the company.

Table 3: Financial Reporting, Audit and Disclosures

\begin{tabular}{|c|c|c|c|c|c|}
\hline Company & $\begin{array}{c}\text { Overseeing } \\
\text { Financial Reporting } \\
\text { Process }\end{array}$ & $\begin{array}{l}\text { Presence of } \\
\text { Financial } \\
\text { Experts }\end{array}$ & $\begin{array}{l}\text { Provision for } \\
\text { probing } \\
\text { irregularities }\end{array}$ & $\begin{array}{l}\text { Review of } \\
\text { Quarterly } \\
\text { Reports }\end{array}$ & $\begin{array}{l}\text { Specific Committee } \\
\text { to oversee } \\
\text { implementation of } \\
\text { the policy }\end{array}$ \\
\hline TCS & $\mathrm{Y}$ & $\mathrm{Y}$ & $\mathrm{Y}$ & $\mathrm{Y}$ & $\mathrm{Y}$ \\
\hline Reliance & $\mathrm{Y}$ & $\mathrm{Y}$ & $\mathrm{Y}$ & $\mathrm{Y}$ & $\mathrm{Y}$ \\
\hline HDFC Bank & $\mathrm{Y}$ & $\mathrm{Y}$ & $\mathrm{Y}$ & Not mentioned & Not Mentioned \\
\hline ITC & $\mathrm{Y}$ & Not Mentioned & $\mathrm{Y}$ & $\mathrm{Y}$ & $\mathrm{Y}$ \\
\hline HUL & $\mathrm{Y}$ & $\mathrm{Y}$ & $\mathrm{Y}$ & $Y$ & $\mathrm{Y}$ \\
\hline Maruti Suzuki & $\mathrm{Y}$ & Not mentioned & $\mathrm{Y}$ & $\mathrm{Y}$ & $\mathrm{Y}$ \\
\hline SBI & $\mathrm{Y}$ & $\mathrm{Y}$ & $\mathrm{Y}$ & Not mentioned & Not Mentioned \\
\hline Infosys & $\mathrm{Y}$ & $Y$ & $\mathrm{Y}$ & $\mathrm{Y}$ & Not Mentioned \\
\hline ONGC & $\mathrm{Y}$ & Not Mentioned & $\mathrm{Y}$ & $\mathrm{Y}$ & $\mathrm{Y}$ \\
\hline PNB & $\mathbf{N}$ & $\mathbf{N}$ & $\mathbf{N}$ & $\mathrm{Y}$ & $\mathrm{Y}$ \\
\hline
\end{tabular}

\subsubsection{Audit Committee's Role with regard to Internal Audit}

Internal audit (IA) consists of reviewing all financial and operational aspects within the company. It is an independent appraisal activity. Effective functioning of the IA significantly enables the board to carry out its governance responsibilities, as reflected in table 4 . The AC of all the companies properly reviews the working of internal auditors' thereby ensuring adequacy of internal control system except for PNB. Review of findings and significant reports is done by all companies to ensure transparency.

Table 4: Internal Audit

\begin{tabular}{|l|l|l|l|l|}
\hline Company & $\begin{array}{l}\text { Committee Reviews } \\
\text { Internal Auditors } \\
\text { Performance }\end{array}$ & $\begin{array}{l}\text { Ensure the adequacy of } \\
\text { Internal Control System }\end{array}$ & Review of findings & $\begin{array}{l}\text { Review of significant } \\
\text { reports }\end{array}$ \\
\hline TCS & Y & Y & Y & Y \\
\hline Reliance & Y & Y & Y & Y \\
\hline HDFC Bank & Y & Y & Y & Y \\
\hline ITC & Y & Y & Y & Y \\
\hline HUL & Y & Y & Y & Y \\
\hline Maruti Suzuki & Y & Y & Y & Y \\
\hline SBI & Y & Not mentioned & Y & Y \\
\hline Infosys & Y & Y & Y & Y \\
\hline ONGC & Y & Y & Y & Y \\
\hline PNB & N & N & N & N \\
\hline
\end{tabular}

Source: Websites of selected companies

\section{1.4 Audit Committee's Role with regard to External Audit}

The audit committee mechanism definitely helps in conduct of external audit. It sets a platform for external auditors for submitting their annual report (see Table 5). The external auditors duly take into consideration the analyses, findings, recommendations of audit committee and also hold discussions, if required. Related party transactions is an important law which helps companies to take care of transactions happening and see that they don't have any chances of conflict with company's interest. 
Table 5: External Audit

\begin{tabular}{|c|c|c|c|}
\hline Company & Related Party Transactions & $\begin{array}{c}\text { Discussion with } \\
\text { External Auditors and } \\
\text { Post-audit Discussions } \\
\end{array}$ & $\begin{array}{c}\text { Review of the } \\
\text { Performance of } \\
\text { External Auditors }\end{array}$ \\
\hline TCS & $\mathrm{Y}$ & $\mathrm{Y}$ & $\mathrm{Y}$ \\
\hline Reliance & $\mathrm{Y}$ & $\mathrm{Y}$ & $\mathrm{Y}$ \\
\hline HDFC Bank & $\mathrm{Y}$ & Not Mentioned & Not Mentioned \\
\hline ITC & $\mathrm{Y}$ & $\mathrm{Y}$ & $\mathrm{Y}$ \\
\hline HUL & $\mathrm{Y}$ & $\mathrm{Y}$ & $\mathrm{Y}$ \\
\hline Maruti Suzuki & $\mathrm{Y}$ & Not Mentioned & Not Mentioned \\
\hline SBI & $\begin{array}{l}\text { "The Bank has not entered into any materially significant } \\
\text { related party transactions with its Promoters, Directors, or } \\
\text { Management, their subsidiaries or relatives, etc., that may have } \\
\text { potential conflict with the interests of the Bank at large". }\end{array}$ & Y & $\mathrm{Y}$ \\
\hline Infosys & $\begin{array}{l}\text { "There have been no materially significant related party } \\
\text { transactions, monetary transactions or relationships between } \\
\text { the Company and its directors, the Management, subsidiaries or } \\
\text { relatives, except for those disclosed in the Board's report". }\end{array}$ & Not Mentioned & Not Mentioned \\
\hline ONGC & $\mathrm{Y}$ & Not Mentioned & Not Mentioned \\
\hline PNB & $\begin{array}{l}\text { Disclosures given in the annual report but not confirmed } \\
\text { whether the transactions had potential conflict with the } \\
\text { bank's interests }\end{array}$ & $\mathbf{N}$ & $\mathbf{N}$ \\
\hline
\end{tabular}

Source: Websites of selected companies

\subsection{PNB Fraud and Role of Auditors}

The total amount of wilful defaults of PNB as on January 31, 2018 mentioned on PNB website is INR 145.93 billion. Mehul Choksi and Nirav Modi have been identified as the key defaulters (Sahgal, 2018, Dsouza, 2018), in the INR 114 billion fraud who gave shape to this scam along with different firms linked to them by acquiring fake letters of undertaking (LoUs), between 2011 and 2017, from PNB's Brady House branch in Mumbai (Jha, 2018). This was done with the purpose to raise loans from Overseas Indian banks for import of diamonds. In its FIR, PNB also said that its employees were able to send messages on SWIFT (Society for Worldwide Interbank Financial Telecommunications) that provided bank credit to Nirav Modi's companies, which those employees did not log into the Core Banking Solution (CBS)- main online banking account. It is not the first time that any fraud happened at PNB. In 2013 also PNB bank, along with a few others, was involved in a similar kind of fraud. A syndicate of banks lent INR 68 billion to Winsome Diamond Group. But instead of LoUs, that was done through issuance of standby letter of credit (LC) to overseas banks which became the liability of banks that had issued the LCs.

\subsubsection{Possible loopholes}

As per Section 143 (12) of the Companies Act of 2013, "auditor of a company can immediately report the matter to the government in case he feels and has reasons to believe that a fraud is being or has been committed against the company by officials or employees of the company". Documents of the PNB show that the audit committee was well aware of its weak audit and scrutiny system. For two years, between 2015 and 2017, the PNB did not have required number of independent board members on the AC which allowed the fraud to perpetuate.

Figure 2: Documents to be Verified

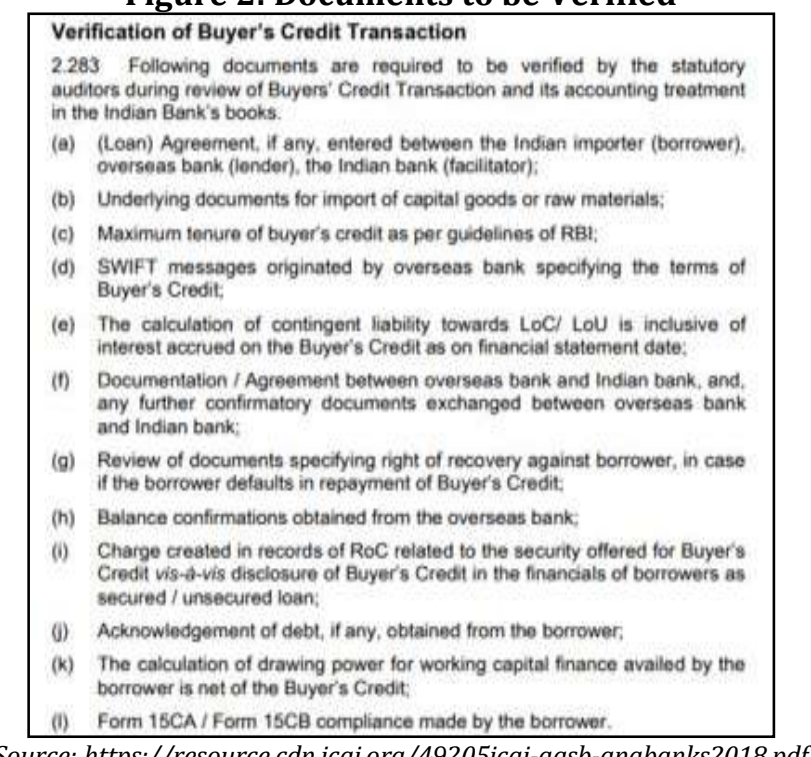


Auditors should have checked the SWIFT records independently and cross-verified them against the CBS, which they did not do. The auditors of the bank should have checked all the documents properly as laid down by ICAI in its guidance note for audit of banks (see Figure 2).

Had they checked all the above mentioned documents, the scam would not have reached such mammoth proportions. Further, a forensic auditors say that it is not possible for auditors to check every transaction even at branches which deals with foreign exchange, so they look mainly at those segments of lending where they notice sudden increase or decrease over the years. This fact can also not be used by the auditors in their defence, as PNB did see sudden changes in lending to the gems and jewellery sector. The loans extended to customers through LoUs are classified as part of the non-fund based offshore loans. The funded loans - which typically require the bank to give the money right away to the customer - galloped from INR 26.65 billion to INR 236.02 billion over the same period. So though there was a significant change in lending but that went unnoticed for years.

Figure 3: PNB Overseas Funding

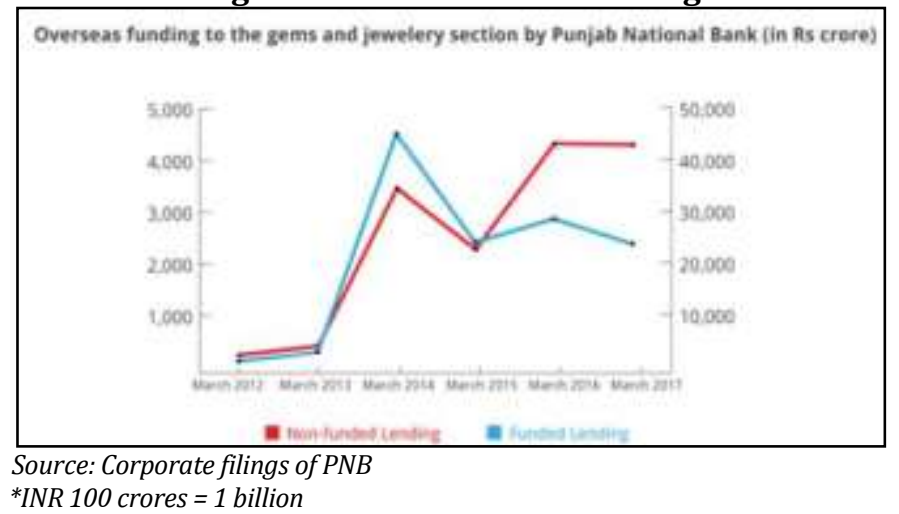

Auditors are also required to check commissions or fee separately. If that would have done properly, they would have noticed the discrepancy in the number of LoUs moving through the SWIFT software and the missing commissions against them in the bank's CBS. But that was also not done properly.

\section{Conclusions}

Before the Enron scam, most countries in the world did not feel the need for independent public oversight to regulate the conduct of companies. Although there were initiatives taken to elaborate on the audit report and revise the guidelines for conducting audits, those initiatives were regarded as inadequate following a succession of financial reporting debacles in the United States and Europe between 2001 and 2003. Governance failure has now become a major problem in many companies across the world. With the result, regulators have increased their focus on laying down codes and standards for good governance.

In India, none of the existing efforts at that time to improve corporate governance were effective in preventing the spectacular failure of Satyam Computer Services Limited (hereafter, Satyam) in January 2009. Satyam was audited by Lovelock \& Lewes, a member of the PricewaterhouseCoopers (PwC) International network, and it had outside directors with impressive profiles. "India's Enron" has led to questions about the quality of accounting, auditing, and governance in India and in other emerging markets.

Severe corporate governance problems emerge out of the Satyam scandal like; unethical business conduct and behavior, unwarranted acquisitions, lack of vigilance by board, insider trading, earnings management, role of independent directors, external auditors' negligence, dubious behavior of audit committee, sloppiness of rating agencies, untrue disclosures, pledging of shares by promoters, flawed ownership model; etc; are the major governance problems/flaws noticed in the collapse of Satyam.

In India, some people want to setup an independent "public accounting oversight board", while others believe otherwise. Those who supported the formation of an oversight board base their arguments on the competence of ICAI and its independence. They feel that ICAI is capable of legally carrying out most of the necessary functions detailed the SOX Act except for prosecution and levying of penalties.

The independence in the constitution and function of the AC is very important for CG. However, to what extent this independence works in actual practice depends on the individuals who become directors in companies and members of such committees. The right of the BoD to not to consider the recommendations of AC may in some cases make the working of the AC difficult and frustrating, especially in companies where majority shares are held by family groups. When a company is family-owned, practical recommendations from the committee may be turned down by the board, and approved in the AGM. Also, the terms of reference of the AC have to be approved by the board, and if the board does not want any specific issue to be investigated by the $\mathrm{AC}$, the $\mathrm{AC}$ on its own may not be able investigate such issues outside its terms of 
reference. Hence, there is a need to give power and freedom to the AC to decide issues on its own when necessary, after recording the necessary reasons.

Setting up the audit committee has enhanced the credibility of financial statements, increased transparency in financial reporting, and ensured the independence of statutory auditors, thereby playing a significant role in corporate governance. Transparent and honest financial reporting is an indicator of good CG, and good CG not only makes corporate publicly accountable, but also contributes to its better business existence.

\section{References}

1. Auci, S. (2006), Corporate Governance and Firm Performance: A Comparative Analysis of Auditing Problems, Corporate Ownership and Control, Volume 4, Issue 1, doi:10.22495/cocv4i1c1p2

2. Beisland, L. A., Mersland, R., and Strom, R. O. (2015), Audit Quality and Corporate Governance: Evidence from the Microfinance Industry, International Journal of Auditing, Volume 19, Issue 3, 218-237. doi:10.1111/ijau.12041

3. Christopher, J. (2012), Corporate Governance: Exploring the Changing Governance Control Paradigm and its Implications for Internal Auditing, SSRN Electronic Journal. doi:10.2139/ssrn.1980050

4. Co-operation and Development, O. for E. (1999), OECD Principles of Corporate Governance. SSRN Electronic Journal. doi:10.2139/ssrn.174229

5. Dsouza, S. (2018), How Nirav Modi Pulled Off The PNB Fraud, available at https://www.bloombergquint.com/business/the-complexity-of-pnb-fraud\#gs. BCtW6XY

6. Elbardan, H., and Kholeif, A. O. R. (2017), ERP, Internal Auditing and Corporate Governance, Enterprise Resource Planning, Corporate Governance and Internal Auditing, 13-54. doi:10.1007/978-3-319-54990-3_2

7. Hay, D., Stewart, J., and Botica Redmayne, N. (2016), The Role of Auditing in Corporate Governance in Australia and New Zealand: A Research Synthesis, SSRN Electronic Journal . doi:10.2139/ssrn.2838066

8. Importance of Effective Corporate Governance (2015), In Sarbanes-Oxley Internal Controls, R. R. Moeller (Ed.). doi:10.1002/9781119197119.ch12

9. Jha, S. (2018), PNB issued 1,213 fake LoUs to Nirav Modi's firms since March 2011: Jaitley, available at : https://www.business-standard.com/article/finance/pnb-issued-1-213-fake-lous-to-nirav-modi-s-firms-since-march2011-jaitley-118031301190_1.html

10. Joksimovic, M., and Alseddig, A. (2017), The Internal Audit as Function to the Corporate Governance, Megatrend Revija, Volume 14, Issue 2, 109-125. doi:10.5937/megrev1702109j

11. Kurihama, R. (2007). A New Perspective on Relationship between Corporate Governance and Auditing. Issues In Social And Environmental Accounting, Volume 1, Issue 2, 258. doi:10.22164/isea.v1i2.17

12. La Porta, R., Lopez de Silanes, F., Shleifer, A., and Vishny, R. W. (2000), Investor Protection and Corporate Governance, SSRN Electronic Journal . doi:10.2139/ssrn.183908

13. Lessambo, F. I. (2018), Corporate Governance, Accounting, and Auditing Scandals, Auditing, Assurance Services, and Forensics, 395-409. doi:10.1007/978-3-319-90521-1_23

14. Mahdavi, G., and Daryaei, A. A. (2016), Attitude Toward Auditing, Marketing and Corporate Governance (An Examination based in Parsons' Social Action Theory), International Journal of Corporate Social Responsibility, Volume 1, Issue 1. doi:10.1186/s40991-016-0010-8

15. Mihret, D. G., and Grant, B. (2017), The Role of Internal Auditing in Corporate Governance: A Foucauldian Analysis, Accounting, Auditing \& Accountability Journal, Volume 30, Issue 3, 699-719. doi:10.1108/aaaj-10-2012-1134

16. Mohamad, S. (2004), The Importance of Effective Corporate Governance, SSRN Electronic Journal. doi:10.2139/ssrn.617101

17. Pagano, M., and Immordino, G. (2012), Corporate Fraud, Governance, and Auditing. Review of Corporate Finance Studies, Volume 1, Issue 1, 109-133. doi:10.1093/rcfs/cfs001

18. Porte, M., Saur-Amaral, I., and Pinho, C. (2018), Research in Auditing: Main Themes, Revista Contabilidade \& Finanças, Volume 29, Issue 76, 41-59. doi:10.1590/1808-057x201804410

19. Rodgers, W., Choy, H., and Guiral-Contreras, A. (2007), Independent Auditing Involvement with Corporate Governance Issues, Corporate Ownership and Control, Volume 5, Issue 1. doi:10.22495/cocv5i1p2

20. Sahgal, R. (2018), Nirav Modi's Companies used most of PNB funds to buy fixed assets abroad: ED, available at : https://economictimes.indiatimes.com/industry/banking/finance/banking/nirav-modis-companies-used-most-of-pnbfunds-to-buy-fixed-assets-abroad-ed/articleshow/63211990.cms

21. SEBI circular (2000)Corporate Governance, available at :https://www.sebi.gov.in/legal/circulars/feb-2000/corporategovernance 17930.html

22. Shleifer, A., and Vishny, R. W. (1997), A Survey of Corporate Governance, The Journal of Finance, Volume 52, Issue 2, 737. doi:10.2307/2329497

23. Sonu, C. H., Choi, A., and Ahn, H. (2017), Audit Fee Structure, Financial Crisis and Corporate Governance, Korean Accounting Journal, Volume 26, Issue 6, 161-202. doi:10.24056/kaj.2017.11.005

24. United Kingdom Shareholders' Association, 1992, Comments on the draft 'Cadbury' Report, available at : https://www.uksa.org.uk/sites/default/files/press_releases/19920727_uksa_on_cadbury.pdf 